\title{
The Role of Media, Word of Mouth, and Subjective Norms in determining Attitude and Intentions to Purchase Family Takäful Schemes
}

\author{
Shahab Aziz ${ }^{1 *}$, Zahra Afaq ${ }^{2}$, Lakhi Muhammad ${ }^{3}$, Basharat Khan ${ }^{4}$ \\ ${ }^{1}$ Business Studies Department, Bahria University, Islamabad, Pakistan \\ 2,3 Capital University of Science and Technology, Islamabad, Pakistan \\ ${ }^{4}$ Hazara University, Mansehra, KPK, Pakistan
}

\section{Keywords}

Participation Intention

Word of Mouth

Media Referent

Family Takāful

Received: 01 October 2019

Accepted: 10 February 2020

\begin{abstract}
The paper investigate the factors affecting individual's intention towards purchase of family takâful schemes and to investigate the impact of media referent and word of mouth on subjective norms. The study also examines the influence of subjective norms on attitude and intention for purchase of family takâful schemes. The study data were collected from 377 salaried individuals. The data was analysed by variance based partial least squares structural equation modeling (PLS-SEM).The results of the study shows that word of mouth and media referent are significant determinants of subjective norms, while subjective norms have a significant relationship with both attitude and intention to purchase family takâful schemes. Attitude towards family takâful is also a significant determinant of purchase of family takāful.
\end{abstract}

KAUJIE Classification: I44, H21, H22, P1

JEL Classification: C3, D14, G22, Z12

(C) 2020 JIBM. All rights reserved.

\section{INTRODUCTION}

Insurance is a risk management technique where the risk of a loss is transferred from one entity to another in return for an amount called premium. The elements which sell protection products are called insurance agencies. Insurance agencies pool the assets to ensure and support the poor (Brown \& Kim, 1993). Without any insurance cover, the individuals or groups have to bear the risk themselves. Islam, as a religion, characterizes standards on almost every aspect of human life. In the Islamic economic system, interest, gambling, uncertainty, and Liquor are prohibited (Amin, Rahman, Sondoh Jr, \& Hwa, 2011). Islam alos guides human beings to manage and mitigate risks to avoid losses. Further, In Islamic system, risk can be managed or mitigated, but not transferred to any other, as in the latter case the

${ }^{*}$ Corresponding author: Shahab Aziz

†Email: .shahabaziz7@hotmail.com; Saziz.buic@bahria.edu.pk 
exchange becomes commutative as the case of insurance. Takâful system, as suggested in Islamic finance, has to be non-commutative (Ayub, 2014).

Insurance contradicts Islamic Sharī'ah because of the presence of Gharar, Maisir, Riba which are prohibited in Islam. Islamic and conventional insurance frameworks are not the same and are conceptually different (Hamid \& Rahman, 2011). There is rib $\bar{a}$ in insuarnce as the premium amonts are invested in ribā based modes. Mahmood (1991) states that gharar in insurance is identified with the exchange in question, and maisir is included when an insurance agency pays guarantees more than the premium paid.

Like Islamic banking, takāful has also evolved in Muslim as well as non-Muslim countries. According to Ernst \& Young Global Limited (EYGM) (2014), the worldwide takâful market had reached over US $\$ 20$ billion with a yearly development pace of $14 \%$. As indicated by this report, Saudi Arabia was driving the takâful market with practically half of the worldwide share. Regardless of the competition with the conventional insurance, family takâful is as yet an awesome zone to extend the piece of the overall industry.

Pakistan has a huge population of more than 200 million and almost $98 \%$ of the population is Muslim which shows huge potential of takâful. However, insurance penetration, has remained very low i.e. 0.7 percent of GDP over the last decade and has recently increased to $0.9 \%$ of GDP which is the third-lowest in Asia (Sigma 03/2018). There is gigantic potential for family takāful business and takāful organizations are developing and the current portion of takâful in insurance industry remains at 5\% which is not exactly the portion of Islamic banking in the absolute banking in the nation that is $10 \%$. Takâful organizations are offering both family and general takâful spreads. Nonetheless, there exists a huge potential market that is still untapped.

Family takâful companies are facing the challenge of stiff competition from conventional life insurance companies. To better compete with the insurance companies takâful companies needs effective marketing strategies to develop and expand their presence in overall industry. For developing an effective marketing strategy, it is vital for family takäfulcompanies to explore and find out underlying factors which contribute towards attitude and intentions to participate in takäful schemes. This leads to find the answer of why people purchase takäful and what are the driving force which stimulates people towards buying takäful schemes? The present study is an attempt to answer these questions.

Behavioural theories i.e. Theory of Reasoned Action (TRA) and Theory of Planned Behavior (TPB) have long been used to study consumer behavior (Aziz, Md Hussin, \& Husin, 2017; Bigne, Andreu, Hernandez, \& Ruiz, 2018; Husin \& Ab Rahim, 2016; Nguyen, de Leeuw, \& Dullaert, 2018). The present study uses TRA and TPB as a starting point to develop a framework for the study. The present study aims to find out the role of media and word of mouth in explaining subjective norms and attitudes which determines the participation intention regarding family takâful. There are few justifications to select Pakistan for the present study. Initially, takâful is a Sharī'ah -consistent substitute of ordinary insurance and it focuses on the Muslim populace and 98\% of the populace is Pakistan is Muslim. Furthermore, it has been progressively growing in last 10 years since takāful has been introduced in Pakistan. However the share of takäful in the overall insurance industry is very 
small. In this context, the current investigation will help in distinguishing the precursors of emotional standards and disposition which might be potential determinants of goal for cooperation in family takâful plan.

\section{LITERATURE REVIEW}

\section{An Overview of Takäful}

Takâful is a kind of insurance in Islam in which people contribute their money being a member and guarantee each other (member) with the loss or any kind of damages in the future. This is an alternative to the conventional insurance. History of takâful can be followed back to approximately fourteen centuries before the Holy Prophet Muhammad (SAW) as an antiquated Arab's act of the idea of al-aqilah (Billah, 2003). The idea of 'aqila' was that all the people from any Arab clans will undoubtedly pay cash in commitment to pay blood cash to the beneficiaries of the person in question. The intention was to give pay and money related assistance to the casualty's family. Holy Prophet and his allies affirmed this idea as an insurance apparatus (Billah, 2003).

The modern takâful practice began from Sudan in the year 1979. Since its beginning takāful business has been developing in Muslim and Non-Muslim nations. The key takâful markets players are Saudi Arabia, UAE, and Malaysia. South Asia and Africa takäful have small market share. As indicated by Ernst and Young (EY) Global takāful Insights, 2014 worldwide gross share remained at US\$14 Billion. As per the report Year on year development rate declined from $22 \%$ (2007-2011) to 14\% (2012-2014). In any case, the development rate was remarkable in ASEAN nations (Malaysia, Indonesia, Brunei, Singapore, and Thailand) which remained at 22\%. In GCC nations (barring Saudi Arabia) development rate was lower for example 14\%. In Pakistan, takäful organizations began their business in 2005. The key takāful markets players are Saudi Arabia, UAE, and Malaysia. South Asia and Africa takāful have a by and large little bit of the general business. However, window takâful was allowed in 2012 by the Securities and Exchange Commission of Pakistan. Presently there are five full-fledged takâful organizations operating in Pakistan. Most of the conventional insurance companies working in Pakistan has its takâful window. As indicated by the Pakistan Islamic Finance Report PIFR (2016), the commitment of protection premium remained at $0.9 \%$ of GDP, while the takāful division's commitments were just $0.04 \%$ of GDP. The low takāful commitments show the presence of tremendous undiscovered takāful markets.

\section{HYPOTHESIS DEVELOPMENT}

\section{Media Referent and Subjective Norms}

The media referent are frequently the most fast and effective methods for advising a crowd of people regarding possible adopters about the presence of advancement, that is, to make mindfulness information (Rogers, 1995). The media incorporate all the media of transmitting messages, for example, the radio, TV, papers, and online notice, web-based life and street appears. As per Ernst \& Young Global Limited (EYGM) (2014), print media is the most predominant publicizing apparatus $(28 \%)$ trailed by outside promotion $(13 \%)$, radio $(12 \%)$, 
web-based life (12\%), online ad (10\%) and TV/film (7\%). As indicated by Rogers (1995), media referent has a few favorable circumstances as far as a way to deal with the crowd, information, and spreading data.

As indicated by Agarwal and Prasad (1998) media referent channel has an informational role. An examination directed by Bhattacherjee (2000) concerning electronic trade selection has indicated that media affects the appropriation of takäful. In writing, different results have been found in literature regarding the effect of media referent on choice standards (Conner, Kirk, Cade, \& Barrett, 2001; Limayem, Khalifa, \& Frini, 2000; Zolait \& Ainin, 2009). The after effects of these examinations show that media referents affect emotional standards.

The impact of media referent on subjective norms in the financial service industry has been studied previously. A study by Husin, Ismail, and Ab Rahman (2016) and Ayinde and Echchabi (2012) on Islamic insurance has proved that media referent had a significant positive relationship with subjective norms. According to Rogers (1995), the role of media is very important in early stages of products innovations. Keeping in view the importance of media in determining subjective norms and limited studies on family takâful context, it seems appropriate to study in the family takafful context. Based on the extant literature, the following hypothesis is formulated.

H1: There is a positive relationship between Media referent and Subjective norms for participation in family takâful schemes.

\section{Word of Mouth and Subjective Norms}

Word of Mouth (WOM) correspondence has for some time been considered as one of the basic considerations in shopper conduct examines molding the mentality and conduct of purchasers. WOM is characterized as non-business and casual sharing of data among individuals about a brand, item, or administration (Anderson, 1998; Arndt, 1967; Crocker, 1986). Eye correspondence is included in WOM (Arndt, 1967; Godes \& Mayzlin, 2004). The most helpful technique for correspondence is WOM (Rogers, 1995). The spearheading concentrate by Katz and Lazarsfeld (1955) demonstrated that WOM helped in buying household items.

As indicated by Villanueva, Yoo, and Hanssens, (2008), "Clients gained through informal (WOM) are bound to be steadfast than the clients using customary showcasing media". Nowadays, WOM expects a critical activity in scattering information to others and clients feel that it is a reliable hotspot for them to choose purchase decisions. Arndt (1967) characterized WOM as the "oral, individual to individual correspondence between a beneficiary and a communicator whom the recipient sees as non-business, concerning a brand, an item or an assistance". Literature expressed that the most powerful sources are companions and associates, and these are the best wellsprings of WOM. Along these lines, customers' dynamic strategies are out which are influenced by WOM, especially during the thing information search stage.

WOM impact in financial services has been proved in many studies. According to File and Price (1992), purchase decisions of financial services are influenced by the opinion of other individuals. Some of the studies have demonstrated a critical effect of WOM on emotional standards (Jalilvand, Samiei, Dini, \& Manzari, 2012; Xia \& Bechwati, 2008; Zolait \& Ainin, 2009). A study conducted by Zolait and Ainin (2009) showed that WOM had 
a significant influence on subjective norms. According to Lada, Tanakinjal, and Amin, (2009) purchaser condition significantly affects his conduct and verbal exchange from a companion, an instructor, and guardians that are noteworthy while deciding abstract standards.

WOM referent can be grouped into two kinds for example individual and indifferent. As indicated by Brown and Reingen (1987) and Duhan, Johnson, Wilcox, and Harrell (1997), friends, family, colleagues are personal sources of referent, while impersonal sources are the comments and writings of columnists, journalists, and publications of experts on the topics. The examinations drove by Hung, Ku, and Chang, (2003) and Pedersen (2005) found that enthusiastic principles are directed by near and dear referent, to be explicit, peer sway, and outside social effect.

Studies by Suddin, Geoffrey, and Hanudin, (2009) and Yap and Noor (2008) found that companions, family, partners, and friends had an extraordinary effect as an individual referent. However, the role of Islamic banks, agents, employers, and religious teachers, in the context of WOM, has been given little consideration in family takâful examination.

According to Ernst \& Young Global Limited (EYGM) (2014), brokers along with retail agents are the most powerful distribution channels. Agents are specially trained marketing individuals who always try to convince and persuade potential customers to buy family takäful. Employers too sometimes arrange for family takăful cover for their employees.

Islamic banks, presently days have a significant job in making mindfulness among masses about Sharī'ah grumbling items. Along these lines, the job of Islamic banks can't be disregarded in clarifying the abstract standards. As indicated by Ernst \& Young Global Limited (EYGM). (2014) takäful is the second biggest dispersion channel after intermediaries. The role of religious teachers and affiliates is important as family takâful is a Sharī'ah -compliant substitute for life insurance. Because of these reasons, the job of Islamic banks, specialists, managers, and strict educators has been talked about in clarifying WOM.

H2: There is a positive relationship between WOM referent and Subjective norms for participationin family takāful schemes.

\section{Subjective Norms and Attitude}

The purchase decisions are influenced by social factors as social pressure is one of the important factor to adopt a certain behaviour (Ajzen \& Fishbein, 1975). Subjective norm is the social pressure exerted on consumer's decision to make choices. TPB and TRA have used subjective norms as one of the constructs to explain buying behavior. According to the TPB, subjective norms not only predict the buying intention but simultaneously affect the attitude. However, the relationship between subjective norms and attitude has been less explored even though few of the studies have proved that there is a significant relationship between subjective norms and attitude (Shimp \& Kavas, 1984; Vallerand, Deshaies, Cuerrier, Pelletier, \& Mongeau, 1992).

The past investigations which have demonstrated the connection between emotional standards and demeanor include moral or good dynamic. These outcomes fortify that the relationship can be tried with regards to the current investigation. These results reinforce that the relationship can be tested in the context of the present study and these outcomes 
fortify that the relationship can be tried with regards to the current investigation. Literature tested the causal link between subjective norms and attitudes and found it significant. The relationship has been less explored in literature and needs to be tested by keeping family takâful in consideration. Therefore, the following mentioned hypothesis is formulated.

H3: There is a positive relationship between subjective norms and attitudes towards adopting family takäful schemes.

\section{Subjective Norms and Purchase Intentions}

Social factors which are influence by the underlying belief structures are subjective norms also called normative beliefs (Ajzen \& Fishbein, 1975). Normative beliefs are related to the sensitivity of individual's choices to purchase. Moreover in normative belief the aspect of subjective norms along with their importance is assessed.

Some of the previous literature posits that subjective norms have limited effect on behavioural intention (Dabholkar, 1994). The previous studies shows conflicting results hence further study is required to explore this relationship. Studies carried out by Echchabi and Olaniyi (2012); Hanudin and Rosita (2011) and Pedersen (2005) have indicated that subjective norms are important predictors of an individual's intentions. In the domain of financial services, the relationship between subjective norms and intentions is tested in many studies (Razak \& Abduh, 2012; Saad, Bidin, Md Idris, \& Hussain, 2010).

Studies carried out in multiple disciplines have shown significant role of subjective norms in Islamic insurance (Omar \& Frimpong, 2007); Islamic house finance products (Sheikh Ali \& Jama, 2016; Amin, Rahman, \& Razak, 2014; Razak and Abduh (2012); internet banking Nor and Pearson (2013), Juwaheer, Pudaruth, and Ramdin, (2012) and Amin (2009). However, a few studies as conducted by Husin et al. (2016), Husin and Rahman (2016) and Syed, Rohani, and Badrul, (2012) found that subjective norms were not significant determinants of behavioral intentions. The conflicting results in previous studies show that it is important to carry out more studies.

H4: There is a positive relationship between subjective norms and an individual's intentions to participate in family takâful schemes.

\section{Attitude and Family Takäful Purchase Intention}

Attitude is a belief system which showsbehavioural tendencies towards socially important objects (Vaughan \& Hogg, 2005). It is a psychological tendency to evaluate and act in favour or against anything (Eagly \& Chaiken, 1993). It can also be said that an attitude is the tendency of expressing favorable or unfavorably (Suki, 2010). Human intentions and behaviours are dependent upon attitude towards that behaviure (Phau \& Teah, 2009). People most often choose the option for which they have higher attitude (Arvola, Lahteenmaki, \& Tuorila, 1999). The extant literature have posits that attitude influences choice of products or services (George, 2002; Jamal \& Ahmed, 2007; Md. Taib, Ramayah, \& Razak, 2008).

The extent literature.; Sheikh Ali and Jama (2016) Amin et al. (2014) Wahyuni, Sakur, and Arifin, (2013); Amin (2012); Juwaheer et al. (2012); Husin and Ab Rahman (2016) have shown that attitude and intention have a positive relationship. More grounded aura prompts 
more grounded lead objectives to purchase. Regardless, two or three past examinations have found a negative association among air and lead desires (Armitage, 2005; Othman et al., 2019). As the previous studies show inconsistent results, the phenomenon needs to be explored further.

H5: An individual's intentions are positively influenced by attitudeforparticipationin family takāful schemes.

\section{Conceptual Framework}

The proposed conceptual framework is in the figure below:

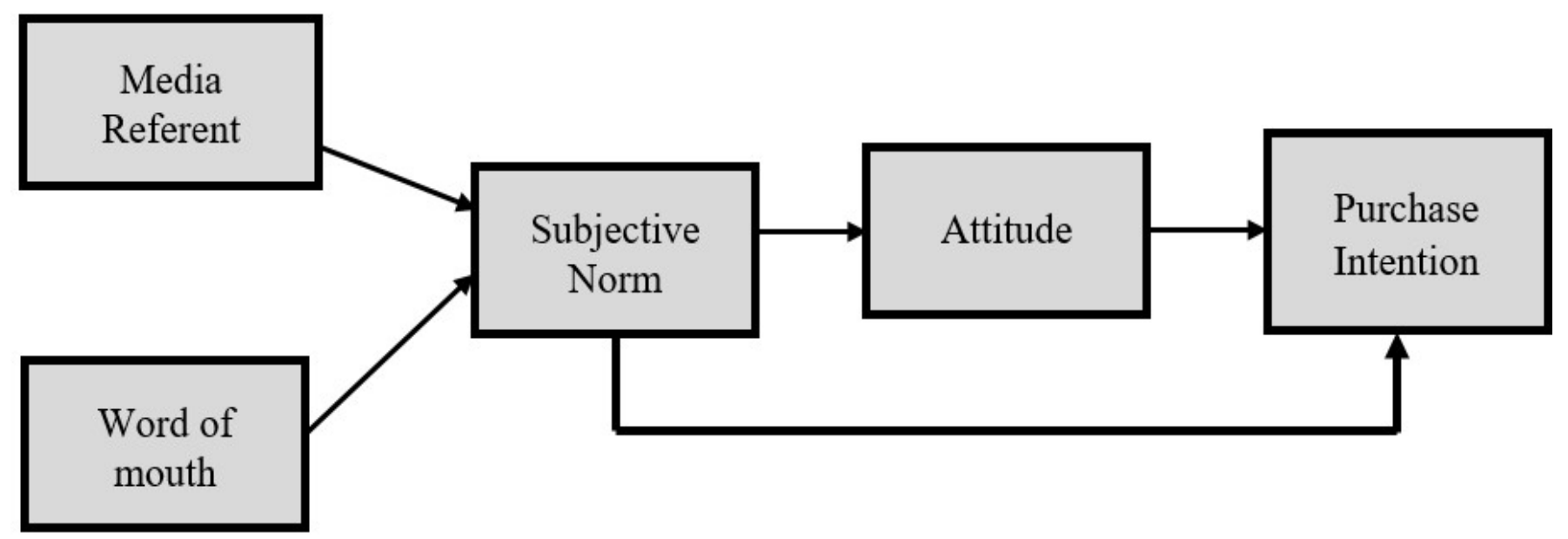

FIGURE 1. Proposed conceptual framework

\section{RESEARCH DESIGN}

Unit of analysis for the present study are the salaried individuals belonging to the working class of the society who are not availing any takâful or insurance cover and represent the main target market for the takâful companies to offer their schemes as they are most vulnerable to the uncertainties in terms of financial loss. The members were asked before filling the questionnaire whether they are availing any takäful or insurance or not. The information was gathered from only those people who were not enjoying takâful or insurance. Two cities of Pakistan have been selected for data collection, Rawalpindi and Islamabad. Both of these cities are also known as twin cities being adjacent to each other. The sample selected ranges between the age 24-50 years. This is also called insurable age as the takaful companies offering their product generally target this age group. People of this age bracket are more likely to be part of this Non-probability, judgmental sampling method has been adopted due to the non-availability of the sampling frame of such individuals. 
The size of the sample selected for this research is 377 which is more than the minimum sample requirement calculated through "G*Power" calculator as recommended for presenting the minimum sample size (Hair Jr, Hult, Ringle, \& Sarstedt, 2016). The required minimum sample size for two predictors, effect size 0.05 , and power 0.95 is 312 . This approach for the calculation of the sample is advantageous and used in literature (Hair Jr, Sarstedt, Hopkins, \& Kuppelwieser, 2014; Ramayah, Yeap, Ahmad, Halim, \& Rahman, 2017). The data was collected during May- December 2017 by distributing questionnaires personally to the target sample. Almost 600 questionnaires were distributed among the respondents belonging to the working class of various industries, and 420 questionnaires were returned and according to this, the response rate of $70 \%$ is observed. However, the usable sample was 377 as the rest of the questionnaires were incomplete and dropped for the analysis.

\section{Research Instrument}

The constructs were measured through a 5-point Likert scale ranging from strongly disagree (1) to strongly agree (5). The items for media have been taken from Pedersen (2005), while word of mouth items have been taken from Husin and Ab Rahman (2016). Subjective norms (4 items) and purchase intention (4 items) have been taken from Khalil (2005). The items for attitude have been adapted from Husin and Ab Rahman (2016). The detailed questionnaire is given in Annexure1.

A pilot study was carried out to establish the reliability of the data before full-scale data collection. The pilot study established the reliability for the sample data as the value of Cronbach's Alpha of all the constructs was above the minimum threshold value of 0.7 as shown in Table I.

TABLE 1

Reliability of Each Construct

\begin{tabular}{lcc}
\hline \hline Name of the Construct & Number of Items & Cronbach's Alpha \\
\hline Purchase Intention & 4 & 0.902 \\
Attitude & 5 & 0.921 \\
Subjective Norms & 4 & 0.897 \\
Media Referent & 4 & 0.829 \\
Word of Mouth & 6 & 0.823 \\
\hline \hline
\end{tabular}

\section{Respondent Profile}

In total, around 377 respondents were considered during the data analysis. From all the respondents, 268 people were male respondents and 109 female who participated in filling the questionnaires. The respondents' profile exhibited that of all the 377 respondents, 164 people were single while 207 people shared a marital status. Furthermore, most of the respondents were between the age of 25-29 years. Most of the respondents for example 198 held a graduate degree, 62 had MS/MPhil/Doctorate degrees, while the rest had a four-year certification. 
TABLE 2

Reliability of Each Construct

\begin{tabular}{llccc}
\hline \hline Demographic & & Number of Respondents & Percent & Cumulative Percent \\
\hline Gender & Male & 268 & 71.1 & 71.9 \\
Age & Female & 109 & 28.9 & 100 \\
& 25-29 years, & 161 & 42.7 & 42.7 \\
& 30-34 years, & 100 & 26.5 & 69.2 \\
& 35-39 years, & 61 & 16.2 & 85.4 \\
& 40-44 years, & 32 & 8.5 & 93.9 \\
Occupational Status & 45-50 years, & 23 & 6.1 & 100 \\
& Public Sector & 92 & 24.4 & 24.4 \\
& Private Sector & 243 & 64.5 & 89.9 \\
& Self Employed & 19 & 5.0 & 93.9 \\
Marital status & Other & 23 & 6.1 & 100 \\
& Single & 164 & 43.5 & 43.5 \\
& Married & 207 & 54.9 & 98.4 \\
& Divorce & 06 & 1.6 & 100 \\
& A-level. Matriculation & 08 & 2.1 & 2.1 \\
& Tech diploma & 07 & 1.9 & 4.0 \\
& Bachelor's Degree & 102 & 27.1 & 31.0 \\
& Master's Degree & 198 & 52.5 & 83.6 \\
& MS/ MPhil/ Doctorate & 62 & 16.4 & 100 \\
\hline \hline
\end{tabular}

TABLE 3

Harman's single-Factor Test

\begin{tabular}{ccccccc}
\hline \hline \multicolumn{2}{l}{ Initial Eigenvalues \& } & & \multicolumn{4}{c}{ Extraction Sum of Square Loadings } \\
\hline \multicolumn{2}{c}{ \% of Cumulative } & & \multicolumn{4}{c}{ \% of Cumulative } \\
Component & Total & Variance & $\%$ & Total & Variance & $\%$ \\
1 & 11.359 & 49.38 & 49.38 & 11.35 & 49.386 & 49.386 \\
2 & 2.706 & 11.76 & 61.15 & 2.706 & 11.767 & 61.153 \\
3 & 1.472 & 6.399 & 67.55 & 1.472 & 6.399 & 67.552 \\
4 & 1.134 & 4.931 & 72.48 & 1.134 & 4.931 & 72.483 \\
\hline \hline
\end{tabular}

Extraction Method: Principal Component Analysis

\section{Common Method Bias}

According to Spector (2006), in quantitative analysis, common method bias may arise when the data is collected from a single source. This issue can be checked through Harman's single factor test once the data is collected. The current research has also used Harman's single factor statistical technique to address this issue. The analysis showed a four-factor solution with a total variance of $72 \%$ and the one factor showed $49 \%$ total variance as shown in Table 3. From the results, it could be gathered that the common method bias issue remained nonexistent. Hence, the researchers can carry on with the data analysis. 
TABLE 4

Validity and Reliability for Constructs

\begin{tabular}{ccccc}
\hline Constructs & Items & Loading & AVE & CR \\
\hline Purchase Intention & PI1 & 0.914 & 0.835 & 0.953 \\
& PI2 & 0.927 & & \\
& PI3 & 0.929 & & \\
Subjective Norms & PI4 & 0.885 & & \\
& SNI & 0.866 & 0.789 & 0.937 \\
& SN2 & 0.906 & & \\
& SN3 & 0.899 & & \\
& SN4 & 0.882 & & \\
Word of Mouth & WOM1 & 0.801 & 0.674 & 0.892 \\
& WOM2 & 0.764 & & \\
& WOM3 & 0.879 & & \\
Media Referent & WOM4 & 0.836 & & \\
& MREF1 & 0.712 & 0.725 & 0.913 \\
& MREF2 & 0.843 & & \\
& MREF3 & 0.763 & & \\
Attitude & ATT1 & 0.891 & 0.786 & 0.948 \\
& ATT2 & 0.894 & & \\
& ATT3 & 0.903 & & \\
& ATT4 & 0.868 & & \\
& ATT5 & 0.877 & & \\
\hline \hline
\end{tabular}

\section{Structural Equation Modeling}

PLS-SEM effectively explains complicated relationships (Sarstedt, 2008). For that reason, Chin (1998) and Rezaei (2015) indicated that to evaluate the measurement model and hypotheses testing, PLS-SEM should be preferred. PLS-SEM is widely used in consumer behavior researches where the objective of the research is to explain the variance in endogenous variable (Henseler, Hubona, \& Ray, 2016; Hair, Ringle, \& Sarstedt, 2011; Rezaei, 2015). Another preferred position of applying PLS-SEM is that it can deal with the informational index that isn't standardized just as estimating the heterogeneity inside the way demonstrating. Aside from that, PLS is additionally fit for taking care of an informational collection in which the information dispersions are not standardized (Vinzi, Trinchera, \& Amato, 2010).Also, PLS is effective in terms of allowing researchers to measure heterogeneity within path modeling (Chin, 2010). Hence PLS-SEM is selected for the present study. So, PLS-SEM will be conducted by using Smart PLS software version 3.2.8 for the current research. PLS-SEM is a two-step process where firstly measurement model is evaluated which is followed by a structural model as discussed in the proceeding sections.

\section{Measurement Model}

The estimation model is typically surveyed to decide the unwavering quality and legitimacy 
(Hair et al., 2014). To evaluate the construct's reliability, composite reliability is measured whose value should be higher than 0.7 (Gefen, Straub, \& Boudreau, 2000; Chin 2010). Similarly, the items' reliability is assessed through the outer loadings which should be higher than 0.70 (Hair, Black, Babin, \& Anderson, 2010). The AVE values specify that the convergent validity should be above 0.5 . Table 4 precisely summarizes the outer loadings of all the items of each construct which are all above 0.7. The composite dependability fulfills the base estimation of 0.7 , subsequently implying merged legitimacy for all examination develops as appeared in Table 4.

TABLE 5

Discriminant Validity

\begin{tabular}{llllll}
\hline Constructs & 1 & 2 & 3 & 4 & 5 \\
\hline Attitude & 0.887 & & & & \\
Intention & 0.806 & 0.914 & & & \\
Media Referent & 0.503 & 0.451 & 0.851 & & \\
Subjective Norms & 0.575 & 0.605 & 0.540 & 0.888 & \\
Word of Mouth & 0.536 & 0.502 & 0.708 & 0.613 & 0.794 \\
\hline \hline
\end{tabular}

TABLE 6

HTMT

Attitude Purchase Media Referent Subjective Norms WOM

Attitude

Purchase Inten- 0.846

tion

$\begin{array}{llll}\text { Media referent } & 0.546 & 0.493 & \\ \text { Subjective } & 0.615 & 0.652 & 0.605\end{array}$

norms

Word of mouth 0.511

0.487

0.713

0.566

Further, to assess the discriminant validity, Fornell and Larcker (1981) criterion were used (Hair et al., 2014) to assess the discriminant validity according to which, the square root of AVE of each construct was paralleled with its correlation of another construct. As displayed in Table 5, the square root of AVE of every construct had a value greater than its correlations with other constructs. Fornell and Lacker criterion is criticized for not being reliable in detecting discriminant validity (Henseler et al., 2016).An improved method to detect the presence of discriminant validity is HTMT.

It is registered as the mean of the considerable number of relationships of the pointers estimating various develops, comparative with the geometric mean of the normal connections of the markers estimating a similar build.SmartPLS generated the HTMT values as shown in Table 6. The criterion for assessment of discriminant validity is that the value should be below the cut of point 0.85 (Kline et al., 2011) or 0.90 (Gold, Malhotra, \& Segars, 2001). 
The data in Table 5 and 6 shows that both the criterion of discriminant validity, fornell and lacker and HTMT are established. Therefore the variables re discriminant from each other.

\section{Structural Model}

Following the analysis of the measurement model, the inner model was assessed. Coefficient of variation and prediction of the modleass was assessed. The Table $7, R^{2}$ for purchase intention was $68 \%$, and subjective norms were $34 \%$. Thus, showing that the model has a sizable explanatory power. To find out the predictive relevance of the model, the blindfolding technique was applied. The criterion for assessment is that If $Q^{2}>0$, then the model does have a predictive relevance. As shown in Table $5, Q^{2}$ for purchase intention was 0.534 , for attitude 0.242 , and for subjective norms, it was 0.294.

Effect-size $\left(f^{2}\right)$ is also evaluating the structural model in which the effect of each individual variable on the dependent variable is examined. According to Cohen (1988), $\left(f^{2}\right)$ of 0.02 is deemed as small, 0.15 is considered as medium and 0.35 is considered as large. Therefore, the effect sizes $\left(f^{2}\right)$ of attitude towards takâful purchase intention are 0.996 subjective norms towards takâful purchase intention is 0.480 i.e. large and media referent towards subjective norms is 0.136 i.e. small. Word of the mouth towards subjective norms is medium i.e. 0.070.

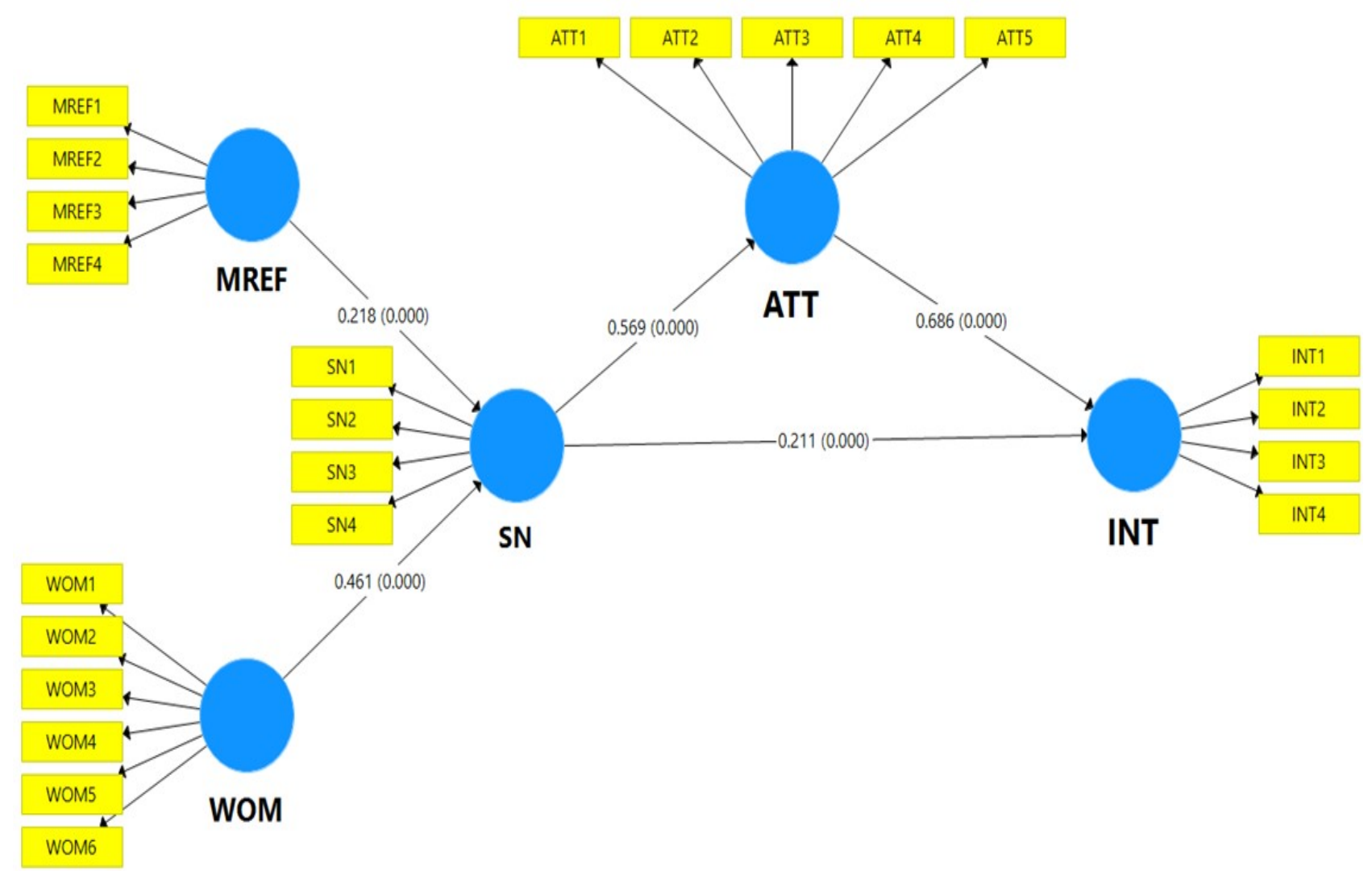

FIGURE 2. Proposed conceptual framework 
TABLE 7

The Goodness of Fit and Predictive Relevance

\begin{tabular}{cccc}
\hline & $R^{2}$ & $\mathrm{Q}^{2}$ & $\left(f^{2}\right)$ \\
\hline Purchase intentions & 0.681 & 0.534 & 0.996 \\
Attitude & 0.324 & 0.242 & 0.480 \\
Subjective Norms & 0.341 & 0.294 & \\
\hline
\end{tabular}

Hypothesis testing was completed and assesses were accomplished for the way coefficients. PLS-SEM algorithm was performed for that purpose. Bootstrapping was applied for a sample of 5,000. Table 8 offers a summary of the posited and hypothesized relationships among the constructs.

H1 showing the relationship between media referent and subjective norms is supported, with $\beta=0.213, p=0.001$ and $t$ statistics 3.271 . H2 shows the relationship between WOM and subjective norms which is also supported, with $\beta=0.463, p=0.000$, and $t$ statistics 7.893. H3 showed the relationship between subjective norms and attitude which was also supported with $\beta=0.575, p=0.000$ and $t$ statistics 14.213. H4 is also supported which shows that subjective norms as a significant determinant of attitude towards family takäful with $\beta=$ $0.212, p=0.000$, and $t$ value 5.365. And lastly, H5 was supported with $\beta=0.685, p=0.000$, and $t$ statistics 19.031 thus, showing a strong significant relationship between attitude and intentions.

The data set for the current research confirmed the hypotheses and supported them. And in the light of the result, the current research has important implications for takäful companies.

TABLE 8

Hypotheses Testing

\begin{tabular}{ccccccc}
\hline Hyp & Relationship & $\beta$ & Std. Error & $t$-value & Decision & $p$-Value \\
\hline H1 & Mref- $>$ SNorm & 0.213 & 0.065 & 3.271 & Supported & 0.001 \\
H2 & WOM $>$ SNorm & 0.463 & 0.059 & 7.839 & Supported & 0.000 \\
H3 & SNorm $>$ Att & 0.575 & 0.040 & 14.213 & Supported & 0.000 \\
H4 & SNorm->Int & 0.212 & 0.039 & 5.365 & Supported & 0.000 \\
H5 & Att $>$ Int & 0.685 & 0.036 & 19.031 & Supported & 0.000 \\
\hline
\end{tabular}

\section{Importance performance Map Analysis}

The Important Performance Map Analysis (IPMA) further provides information about the variables. IPMA analysis helps in identifying the importance of a construct in predicting a targeting construct and their performance. To carry out IPMA, three requirements need to be fulfilled: firstly, the indicators' scales used needs to be at equidistance. Secondly, all the indicators' coding must be in the same direction. Thirdly, outer weight estimates should be positive. The analysis showed that attitude is the most important variable in determining takâful taking intention followed by subjective norms, media referent, and WOM. In terms of performance, attitude is the most important variable followed by WOM, media, and subjective norms. 
TABLE 9

Important Performance Map Analysis

\begin{tabular}{lcc}
\hline \hline Criterion: Investment Decision & Total Effect & Performance \\
\hline Attitude & 0.781 & 60.709 \\
Media Referent & 0.255 & 54.852 \\
Subjective Norms & 0.669 & 52.067 \\
Word of Mouth & 0.195 & 56.697 \\
\hline \hline
\end{tabular}

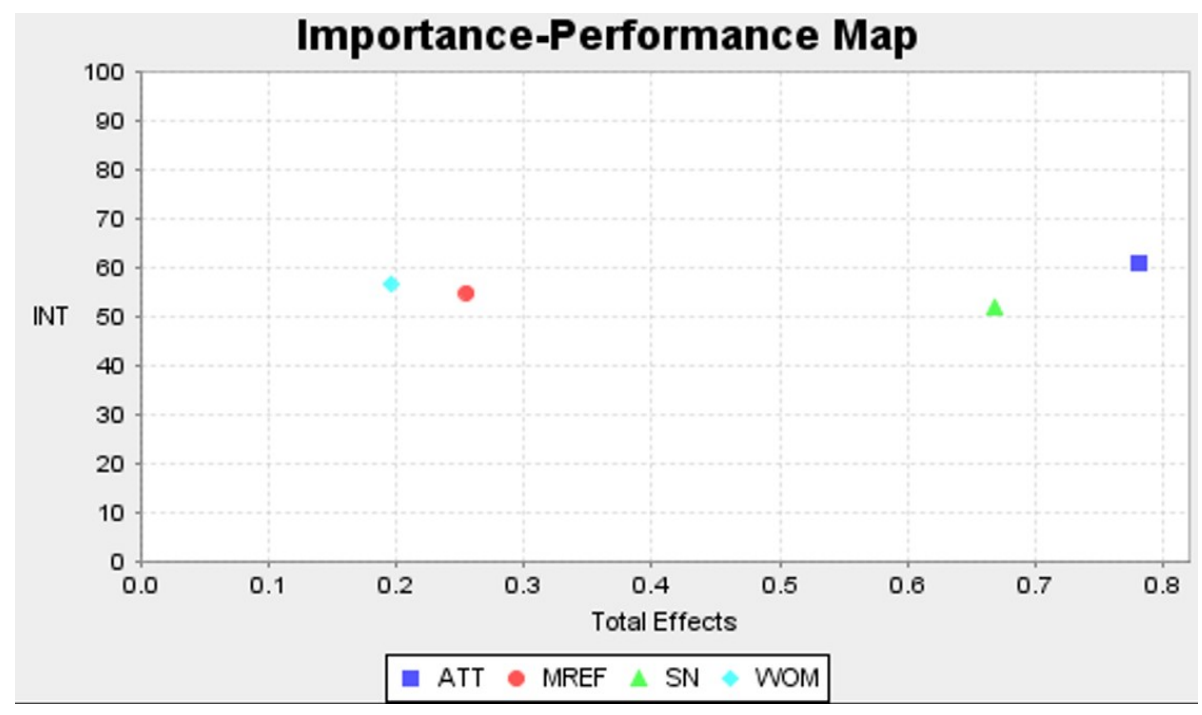

FIGURE 3. Important performance map analysis

\section{Discussion}

The purpose of this study was to examine the influence of WOM and media referent on subjective norms and to find out the influence of subjective norms on attitude and takäful taking intentions. H1 hypothesized the relation between media referent and subjective norms; the findings of the study have confirmed that the subjective norms are positively affected by referent groups. These findings confirm the previous findings of the literature (Ayinde \& Echchabi 2012; Husin et al., 2016). Similarly, H2 hypothesized the relationship of WOM with subjective norms and as predicted according to the previous literature (Jalilvand \& Samiei, 2012; Jalilvand et al., 2012; Zolait \& Ainin, 2009), WOM showed a positive relationship with the subjective norms. The findings of the study confirm that WOM and media referent are significant determinants of subjective norms; however, the WOM channel is stronger as compared to media referent.

$\mathrm{H} 3$ predicted a positive relationship between subjective norms and attitudes. The results confirmed the findings of the prior studies, showing that subjective norms positively affected the attitude (Vallerand et al., 1992). H4 was about the relationship between subjective norms and takâful taking intention. The findings of the study were aligned with the previous literature and can be generalized (Echchabi \& Olaniyi, 2012; Hanudin \& Rosita, 2011; Pedersen, 2005). The results also show that where subjective norms lead to both attitude and intentions to participation family takäful, the influence of subjective norms on attitude is stronger as 
compared to the intentions. H5 showed the relation between the attitude and intentions and as predicted, the results showed a positive and significant relationship between the attitudes and intentions (Sheikh Ali \& Jama, 2016; Husin \& Ab Rehman, 2016).

\section{Implications of the Study}

This study contributes to the body of knowledge in two different ways. Firstly, the study establishes and confirms the relationship between WOM and media referent with the subjective norms. These two constructs contribute significantly to explaining the subjective norms. The clarification of these builds inside the customer setting gives a prevalent comprehension of the takâful administrators in building up the items just as empowering them to upgrade their comprehension of how to showcase their items. This way, the present study furthers the body of knowledge by incorporating WOM and media referent together to explain the subjective norms construct. Secondly, the present study has also proved that subjective norms are a significant determinant of attitude along with intentions that have only been explored in a few studies.

Practically implied, marketing managers can get an enlightening insight from this research. Abstract standards have been demonstrated as a significant determinant of building up a positive goal to taking family takâful plans. In that context, WOM and media referent play a vital role in determining the subjective norms. Takâful companies can create a positive WOM by improving their service quality and increasing the satisfaction level of the existing consumers. Media is likewise a noteworthy device in making mindfulness among masses to profit the chance to relieve their life-related dangers through takâful inclusion.

\section{CONCLUSION}

The current research sought to find out the role of media referent and word of mouth in shaping the subjective norms to predict a positive attitude for purchasing the family takâful schemes. The main purpose of this study was to find the association among attitude and intention of subjective norms and integration of study with family takäful schemes. The study used the theory of planned behavior as its underpinning theory. For that purpose, five hypotheses were formulated and tested in this empirical study. All the hypotheses generated positive and significant results and the findings were in line with the previous literature. The media referent and WOM both had a significant relationship with subjective norms. The subjective norms, in turn, had a significant relation with not only attitude but takäfultaking intentions as well.

The findings of the study that can be generalized in the Pakistani context which can pave a pathway for the takafful operators to increase their customer base through effective marketing strategies keeping in view not only their customers but also their referent groups. Takäful companies can focus on media campaigns by providing the relevant information to their target market. Moreover spreading the information about takâful through referent groups can have significant impact. Therefore takäful companies can disseminating the information regarding takâful in communities through seminars and workshops. The peers groups are very important in shaping the opinion of the individuals therefore these seminars should 
attach the peers and influential people within the communities to create a positive word of mouth. Moreover the services to the existing clients needs to be enhanced which can also help in creating a positive word of mouth. These services can be improved through enhanced customer services, meeting clients expectations, handling claims effectively and timely an providing the return which has been agreed. The satisfied customers can spread the positive attributes to others. This can help in crating a positive attitude which will lead to taking a decision to purchase family takäful schemes.

\section{REFERENCES}

Agarwal, R., \& Prasad, J. (1998). The antecedents and consequents of user perceptions in information technology adoption. Decision Support Systems, 22(1), 15-29. doi: https://doi.org/10.1016/S0167-9236(97)00006-7

Ajzen, I., \& Fishbein, M. (1975). Belief, attitude, intention and behavior: An introduction to theory and research. Journal of Business venturing 5, 177-I89. Amin, H. (2009). An analysis of online banking usage intentions: an extension of the technology acceptance model. International Journal of Business and Society, 10(1), 40-88.

Amin, H. (2012). An analysis on Islamic insurance participation. Jurnal Pengurusan, 34, 11-20. doi: https://doi.org/10.17576/pengurusan-2012-34-02

Amin, H., Rahman, A. R. A., Sondoh Jr, S. L., \& Hwa, A. M. C. (2011). Determinants of customers' intention to use Islamic personal financing: The case of Malaysian Islamic banks. Journal of Islamic Accounting and Business Research, 2(1), 22-42. doi: https://doi.org/10.1108/17590811111129490

Amin, H., Rahman, A. R. A., \& Razak, D. A. (2014). Consumer acceptance of Islamic home financing. International Journal of Housing Markets and Analysis, 7(3), 303-332. doi: https://doi.org/10.1108/IJHMA-12-2012-0063

Anderson, E. W. (1998). Customer satisfaction and word of mouth. Journal of Service Research, 1(1), 5-17. doi: https://doi.org/10.1177/109467059800100102

Armitage, C. J. (2005). Can the theory of planned behavior predict the maintenance of physical activity? Health Psychology, 24(3), 235-245. doi: https://doi.org/10.1037/02786133.24.3.235

Arndt, J. (1967). Role of product-related conversations in the diffusion of a new product. Journal of Marketing Research, 4, 291-295. doi: https://doi.org/10.1177/002224376700400308

Arvola, A., Lahteenmaki, L., \& Tuorila, H. (1999). Predicting the intent to purchase unfamiliar and familiar cheeses: The effects of attitudes, expected liking and food neophobia. Appetite, 32(1), 113-126. doi: https://doi.org/10.1006/appe.1998.0181

Ayinde, L. O., \& Echchabi, A. (2012). Perception and adoption of Islamic insurance in Malaysia: An empirical study. World Applied Sciences Journal, 20(3), 407-415.

Ayub, M. (2014). Making takāful system really worthwhile. Journal of Islamic Business and Management, 4(1), doi: https://doi.org/10.12816/0019133

Aziz, S., Md Husin, M., \& Hussin, N. (2017). Conceptual framework of factors determining intentions towards the adoption of family takäful-An extension of decomposed theory of 
planned behaviour. International Journal of Organizational Leadership, 6, 385-399. doi: https://doi.org/10.33844/ijol.2017.60430

Bhattacherjee, A. (2000). Acceptance of e-commerce services: the case of electronic brokerages. IEEE Transactions on Systems, Man, and Cybernetics-Part A: Systems and Humans, 30(4), 411-420. doi: https://doi.org/10.1109/3468.852435

Bigne, E., Andreu, L., Hernandez, B., \& Ruiz, C. (2018). The impact of social media and offline influences on consumer behaviour. An analysis of the low-cost airline industry. Current Issues in Tourism, 21(9), 1014-1032. doi: https://doi.org/10.1080/13683500.2015.1126236

Billah, M. M. (2003). Islamic and modern insurance: Principles and practices. Kuala Lumpur, Malaysia: Ilmiah Publishers.

Brown, J. J., \& Reingen, P. H. (1987). Social ties and word-of-mouth referral behavior. Journal of Consumer Research, 14(3), 350-362. doi: https://doi.org/10.1086/209118

Browne, M. J., \& Kim, K. (1993). An international analysis of life insurance demand. Journal of Risk and Insurance, 60(4), 616-634. doi: https://doi.org/10.2307/253382

Chin, W. W. (1998). Commentary: Issues and opinion on structural equation modeling. MIS Quarterly, 22(1), 7-16.

Chin, W. W. (2010). How to write up and report PLS analyses. In In E. Vinzi., W. W. Chin, J. Henseler., \& H. Wang (Eds.,), Handbook of partial least squares: Concepts, methods and applications. New York, NY: Springer, Berlin Heidelberg.

Chin, W. W., Henseler, J., \& Wang, H. (2010). Handbook of partial least squares: Concepts, methods and applications. New York, NY: Springer, Berlin Heidelberg. doi: https://doi.org/10.1007/978-3-540-32827-8_29

Cohen, J. (1988). Statistical power analysis for the behavioral sciences (2nd ed.). Hillsdale, NJ: Erlbaum.

Conner, M., Kirk, S. F. L., Cade, J. E., \& Barrett, J. H. (2001). Why do women use dietary supplements? The use of the theory of planned behaviour to explore beliefs about their use. Social Science and Medicine, 52(4), 621-633. doi: https://doi.org/10.1016/S02779536(00)00165-9

Crocker, K. E. (1986). The influence of the amount and type of information on individuals' perception of legal services. Journal of the Academy of Marketing Science, 14(4), 18-27. doi: https://doi.org/10.1007/BF02721812

Dabholkar, P. A. (1994). Incorporating choice into an attitudinal framework: Analyzing models of mental comparison processes. Journal of Consumer Research, 21, 100-18. doi: https://doi.org/10.1086/209385

Duhan, D. F., Johnson, S. D., Wilcox, J. B., \& Harrell, G. D. (1997). Influences on consumer use of word-of-mouth recommendation sources. Journal of the Academy Of Marketing Science, 25(4), 283. doi: https://doi.org/10.1177/0092070397254001

Eagly, A. H., \& Chaiken, S. (1993). The psychology of attitudes. San Diego, CA: Harcourt Brace Jovanovich College Publishers. /item Echchabi, A., \& Olaniyi, O. N. (2012). Malaysian consumers' preferences for Islamic banking attributes. International Journal of Social Economics, 39(11), 859-874. doi: https://doi.org/10.1108/03068291211263907 
Echchabi, A., \& Aziz, H. A. (2012). Empirical investigation of customers' perception and adoption towards Islamic banking services in Morocco. Middle-East Journal of Scientific Research, 12(6), 849-858.

Ernst \& Young Global Limited (EYGM). (2014). Global takâful insights 2014: Update markets: Growth momentum continues. United Kingdom: Author

File, K. M., \& Prince, R. A. (1992). Positive word of mouth: Customer satisfaction and buyer behavior. International Journal of Bank Marketing, 10(1), 25-29. doi: https://doi.org/10.1108/02652329210007867

Fornell, C., \& Larker, D. (1981). Structural equation modeling and regression: Guidelines for research practice. Journal of Marketing Research, 18(1), 39-50.

doi: https://doi.org/10.2307/3151312

Gefen, D., Straub, D. W., \& Boudreau, M. C. (2000). Structural equation modeling and regression guidelines for research practice. Communications of the Association for Information Systems, 4(7), 2-77. doi: https://doi.org/10.17705/1CAIS.00407

George, J. F. (2002). Influences on the internet to make internet purchases. Internet Research: Electronic Networking Applications and Policy, 12(2), 165-180. doi: https://doi.org/10.1108/10662240210422521

Godes, D., \& Mayzlin, D. (2004). Using online conversations to study word of mouth communications. Marketing Science, 23(4), 545-560.

doi: https://doi.org/10.1287/mksc.1040.0071

Gold, A. H., Malhotra, A., \& Segars, A. H. (2001). Knowledge management: An organizational capabilities perspective. Journal of Management Information Systems, 18(1), 185-214. doi: https://doi.org/10.1080/07421222.2001.11045669

Hair, J. F., Black, W. C., Babin, H. J., \& Anderson, R. E. (2010). Multivariate Data Analysis (7th ed.). New Jersey: Prentice Hall. doi: https://doi.org/10.1016/j.jmva.2009.12.014

Hair, J. F., Ringle, C. M., \& Sarstedt, M. (2011). PLS-SEM: Indeed a silver bullet. Journal of Marketing Theory and Practice, 19(2), 139-152. doi: https://doi.org/10.2753/MTP10696679190202

Hair Jr, J. F., Sarstedt, M., Hopkins, L., \& Kuppelwieser, V. G. (2014). Partial least squares structural equation modeling (PLS-SEM). European Business Review, 26(2), 106-121. doi: https://doi.org/10.1108/EBR-10-2013-0128

Hair Jr, J. F., Hult, G. T. M., Ringle, C., \& Sarstedt, M. (2016). A primer on partial least squares structural equation modeling (PLS-SEM). Thousand Oaks, CA: Sage Publications. doi: https://doi.org/10.1108/EBR-10-2013-0128

Hamid, M. A., \& Rahman, N. M. N. A. (2011). Commitment and performance: A case of takâful (Islamic insurance) representatives in Malaysia. Australian Journal of Basic and Applied Sciences, 5(10), 777-785. Hanudin A., \& Rosita C. (2011). Determinants for ar-Rahnu usage intentions: An empirical investigation. African Journal of Business Management, 5(20), 8181-8191. doi: https://doi.org/10.5897/AJBM11.423

Henseler, J., Hubona, G., \& Ray, P. A. (2016). Using PLS path modeling in new technology research: updated guidelines. Industrial Management $\mathcal{E}$ Data Systems, 116(1), 2-20. doi: https://doi.org/10.1108/IMDS-09-2015-0382 
Hung, S. Y., Ku, C. Y., \& Chang, C. M. (2003). Critical factors of WAP services adoption: an empirical study. Electronic Commerce Research and Applications, 2(1), 42-60. doi: https://doi.org/10.1016/S1567-4223(03)00008-5

Husin, M. M., \& Ab Rahman, A. (2016). Predicting intention to participate in family takāful scheme using decomposed theory of planned behaviour. International Journal of Social Economics, 43(12), 1351-1366. doi: https://doi.org/10.1108/IJSE-03-2015-0074

Husin, M. M., Ismail, N.,\& Ab Rahman, A. (2016). The roles of mass media, word of mouth and subjective norm in family takäful purchase intention. Journal of Islamic Marketing, 7(1), 59-73. doi: https://doi.org/10.1108/JIMA-03-2015-0020

Jalilvand, M. R., \& Samiei, N. (2012). The effect of electronic word of mouth on brand image and purchase intention. Marketing Intelligence $\mathcal{E}$ Planning, 30(4), 460-476. doi: https://doi.org/10.1108/02634501211231946

Jalilvand, M. R., Samiei, N., Dini, B., \& Manzari, P. Y. (2012). Examining the structural relationships of electronic word of mouth, destination image, tourist attitude toward destination and travel intention: An integrated approach. Journal of Destination Marketing and Management, 1(1), 134-143. doi: https://doi.org/10.1016/j.jdmm.2012.10.001

Jamal, A. S., \& Ahmed, A. F. (2007). Socio-cultural factors influencing consumer adoption of on-line transactions. Paper presented at the Eighth World Congress on Management of eBusiness (WCMeB), Toronto, Canada. doi: https://doi.org/10.1109/WCMEB.2007.60

Juwaheer, T. D., Pudaruth, S., \& Ramdin, P. (2012). Factors influencing the adoption of internet banking: A case study of commercial banks in Mauritius. World Journal of Science, Technology and Sustainable Development, 9(3), 204-234.

doi: https://doi.org/10.1108/20425941211250552

Katz, E., \& Lazarsfeld, P. F. (1955). Personal influence. Glencoe, Scotland: Free Press.

Kline, E., Wilson, C., Ereshefsky, S., Tsuji, T., Schiffman, J., Pitts, S., \& Reeves, G. (2012). Convergent and discriminant validity of attenuated psychosis screening tools. Schizophrenia Research, 134(1), 49-53. doi: https://doi.org/10.1016/j.schres.2011.10.001

Lada, S., Tanakinjal, G. H., \& Amin, H. (2009). Predicting intention to choose halal products using theory of reasoned action. International Journal of Islamic and Middle Eastern Finance and Management, 2(1), 66-76. doi: https://doi.org/10.1108/17538390910946276

Limayem, M., Khalifa, M., \& Frini, A. (2000). What makes consumers buy from Internet? A longitudinal study of online shopping. IEEE Transactions on Systems, Man, and Cybernetics-Part A: Systems and Humans, 30(4), 421-432.

doi: https://doi.org/10.1109/3468.852436

Mahmood, N. R. (1991). Takāful: The Islamic system of mutual insurance-The Malaysian experience. Arab Law Quarterly, 6(3), 280-296.

doi: https://doi.org/10.1163/157302591X00340

Md. Taib, F. M., Ramayah, T., \& Razak, D. A. (2008). Factors influencing intention to use diminishing partnership home financing. International Journal of Islamic and Middle Eastern Finance and Management, 1(3), 235-248. doi: https://doi.org/10.1108/17538390810901168 
Nor, K. M., \& Pearson, J. M. (2008). An exploratory study into the adoption of internet banking in a developing country: Malaysia. Journal of Internet Commerce, 7(1), 29-73. doi:

Nguyen, D. H., de Leeuw, S., \& Dullaert, W. E. (2018). Consumer behaviour and order fulfilment in online retailing: A systematic review. International Journal of Management Reviews, 20(2), 255-276. doi: https://doi.org/10.1111/ijmr.12129

Omar, O. E., \& Frimpong, N. O. (2007). Life insurance in Nigeria: An application of the theory of reasoned action to consumers' attitudes and purchase intention. The Service Industries Journal, 27(7), 963-976. doi: https://doi.org/10.1080/02642060701570891

Othman, B., Harun, A., Rashid, W., Nazeer, S., Kassim, A., \& Kadhim, K. (2019). The influences of service marketing mix on customer loyalty towards Umrah travel agents: Evidence from Malaysia. Management Science Letters, 9(6), 865-876. doi: https://doi.org/10.5267/j.msl.2019.3.002

Pedersen, P. E. (2005). Adoption of mobile internet services: An exploratory study of mobile commerce early adopters. Journal of Organizational Computing and Electronic Commerce, 15(3), 203-222. doi: https://doi.org/10.1207/s15327744joce1503_2

Phau, I., \& Teah, M. (2009). Devil wears (counterfeit) Prada: A study of antecedents and outcomes of attitudes towards counterfeits of luxury brands. Journal of Consumer Marketing, 26(1), 15-27. doi: https://doi.org/10.1108/07363760910927019

Ramayah, T., Yeap, J. A., Ahmad, N. H., Halim, H. A., \& Rahman, S. A. (2017). Testing a confirmatory model of facebook usage in smartPLS using consistent PLS. International Journal of Business and Innovation, 3(2), 1-14.

Razak, D. A., \& Abduh, M. (2012). Customers' attitude towards diminishing partnership home financing in Islamic banking. American Journal of Applied Sciences, 9 (4), 593-599. doi: https://doi.org/10.3844/ajassp.2012.593.599

Rezaei, S. (2015). Segmenting consumer decision-making styles (CDMS) toward marketing practice: A partial least squares (PLS) path modeling approach. Journal of Retailing and Consumer Services, 22, 1-15. doi: https://doi.org/10.1016/j.jretconser.2014.09.001 Rogers, E. M. (1995). Diffusion of innovations. New York, NY: The Free Press.

Saad, R. A. J., Bidin, Z., Idris, K. M., \& Hussain, M. H. M. (2010). Factors that influenced the business Zakah compliance behaviour. UKM Journal of Management, 30, 49-61.

Sarstedt, M. (2008). A review of recent approaches for capturing heterogeneity in partial least squares path modelling. Journal of Modelling in Management, 3(2), 140-161. doi: https://doi.org/10.1108/17465660810890126

Sheikh Ali, A. Y., \& Jama, A. K. A. (2016). Determinants of Islamic insurance acceptance: Empirical evidence from Somalia. European Journal of Business and Management, 8(15), 102-108.

Shimp, T. A., \& Kavas, A. (1984). The theory of reasoned action applied to coupon usage. Journal of Consumer Research, 11, 795-809. doi: https://doi.org/10.1086/209015

Spector, P. E. (2006). Method variance in organizational research: Truth or urban legend? Organizational Research Methods, 9, 221-232.

doi: https://doi.org/10.1177/1094428105284955 
Suddin, L., Geoffrey, H. T., \& Hanudin, A. (2009). Predicting intention to choose halal products using theory of reasoned action. International Journal of Islamic and Middle Eastern Finance and Management, 2(1), 66-76. doi: https://doi.org/10.1108/17538390910946276 Suki, N. M. (2010). An empirical study of factors affecting the internet banking adoption among Malaysian consumers. Journal of Internet Banking and Commerce, 15(2), 1-11. Syed, S.A., Rohani, M., \& Badrul, H. (2012). Is religiosity an important determinant on Muslim consumer behaviour in Malaysia? Journal of Islamic Marketing, 2 (1), pp. 83-96. doi: https://doi.org/10.1108/17590831111115268

Vallerand, R. J., Deshaies, P., Cuerrier, J. P., Pelletier, L. G., \& Mongeau, C. (1992). Ajzen and Fishbein's theory of reasoned action as applied to moral behavior: A confirmatory analysis. Journal of Personality and Social Psychology, 62(1), 98-109. doi: https://doi.org/10.1037/0022-3514.62.1.98

Vaughan, G., \& Hogg, M. A. (2005). Introduction to social psychology. Melbourne, Australia: Pearson Education Australia.

Villanueva, J., Yoo, S., \& Hanssens, D. M. (2008). The impact of marketing-induced versus word-of-mouth customer acquisition on customer equity growth. Journal of marketing Research, 45(1), 48-59. doi: https://doi.org/10.1509/jmkr.45.1.48

Vinzi, V. E., Trinchera, L., \& Amato, S. (2010). PLS path modeling: From foundations to recent developments and open issues for model assessment and improvement. In E. Vinzi., W. W. Chin, J. Henseler, \& H. Wang (Eds.,), Handbook of partial least squares: Concepts, methods and applications. New York, NY: Springer, Berlin Heidelberg. doi: https://doi.org/10.1007/978-3-540-32827-8_3

Wahyuni, S., Sakur, S., \& Arifin, T. (2013). Knowledge as an antecedent variable of intention to use Islamic banking product. Paper presented at the ASEAN/Asian Academic Society International Conference Proceeding Series, Hat Yai, Thailand.

Xia, L., \& Bechwati, N. N. (2008). Word of mouse: The role of cognitive personalization in online consumer reviews. Journal of interactive Advertising, 9(1), 3-13. doi: https://doi.org/10.1080/15252019.2008.10722143

Yap, S. F., \& Noor, A. (2008). An extended model of theory of planned behaviour in predicting exercise intention. International Business Research, 1(4), 108-122. doi: https://doi.org/10.5539/ibr.v1n4p108 /item Zolait, A. H. S., \& Ainin, S. (2009). The influence of communication channels on internet banking. Asian Journal of Business and Accounting, 2(1\&2), 115-134. 